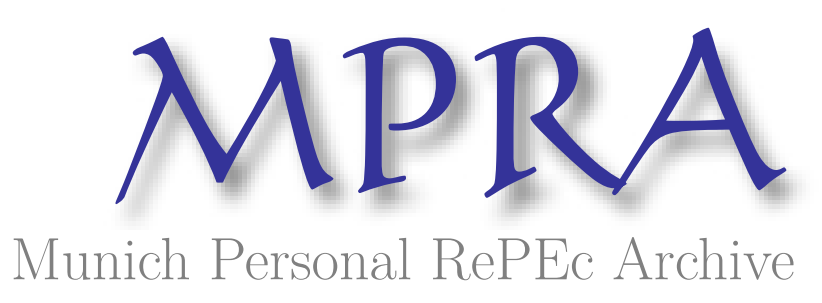

\title{
Sovereign Debt Restructuring After Argentina
}

Porzecanski, Arturo C.

American University

August 2016

Online at https://mpra.ub.uni-muenchen.de/73361/

MPRA Paper No. 73361, posted 28 Aug 2016 20:59 UTC 


\title{
Sovereign Debt Restructuring After Argentina
}

\author{
Arturo C. Porzecanski \\ Distinguished Economist in Residence and \\ Director, International Economic Relations Program \\ American University \\ 4400 Massachusetts Ave. NW \\ Washington DC 20016 \\ Author e-mail: aporzeca@american.edu \\ Author URL: http://www.american.edu/sis/faculty/aporzeca.cfm
}

September 2016

\begin{abstract}
Sovereign debt restructurings may experience marginal changes as a result of recent modifications in contractual terms being incorporated into new bond issues, but for the most part they will likely resemble what has generally worked so well in recent decades to the satisfaction of most governments and private creditors. The statutory reforms that have been proposed to date are highly unlikely to gain traction for a variety of reasons, including the prospect that they would have been stymied when confronted with a rogue sovereign debtor such as Argentina.
\end{abstract}

KEYwORDS: Argentina, default, debt, sovereign, restructuring, statutory; contractual; collective action; pari passu; finance

JEL CoDES: E6, F3, F34, F51, F65, H63, K4, N26, Q15

(C) Copyright 2016 Arturo C. Porzecanski 


\section{INTRODUCTION}

During the late 1990s and early 2000s, a number of academic economists, legal scholars, and policy gurus focused their attention upon the alleged inefficiencies in international financial markets that supposedly had contributed to systemic financial crises throughout Southeast Asia, Russia, Brazil and especially in Argentina, the locus of the world's largest default up to that point in time.

The scribblers argued that globalization had spawned increasingly diverse, diffuse, and unmanageable creditor and debtor communities that posed coordination and collective-action problems. No longer could a relatively small syndicate of commercial banks gather quickly in New York or London, spurred into action by urgent telephone calls from their supervisory authorities, to deal with whatever financial emergency had erupted in some distant corner of the world. As a result, governments that lost the confidence of their bank depositors, bondholders, or bank creditors, or fell victim to regional 'contagion' effects, were claimed to be unable to work out constructive solutions prior to a major currency, banking, or debt crisis.

After a crisis erupted, it was alleged, financial stability could only be restored through the extension of massive loan packages from the G-7 governments acting through the International Monetary Fund (IMF). Moreover, these financial rescues reportedly were generating moral hazard and other adverse systemic risks - particularly in situations where nations' debt sustainability was questionable. And when sovereign liabilities needed to be restructured or written down, the story went, the absence of an orderly sovereign bankruptcy mechanism meant that workouts were delayed, and their effectiveness was undermined, by 'free riders' and 'rogue' (holdout) creditors.

This focus on the alleged shortcomings of financial globalization, and the seeming repetition of currency, banking and/or sovereign debt crises, spawned various concrete proposals to reform the international financial architecture (Porzecanski, 2005). The 'statutory approach' argued for the creation of a supranational bankruptcy authority that would adjudicate financial claims on troubled sovereigns in an expeditious manner, overriding contracts written in national jurisdictions. The 'contractual approach', on the other hand, called for the modification of boilerplate bond clauses especially under New York law - in ways that would facilitate communication among creditors and with the sovereign debtor, restrain disruptive litigation, and enable restructuring decisions by a qualified majority of creditors rather than by unanimous consent.

Initially, several academics urged, and the G-7 governments favored, consideration of both approaches. However, this was generally resisted by both the financial industry and the largest sovereign issuers in the emerging markets. In the end, the government of Mexico and its bankers decided to issue a bond, in early 2003, subject to New York law but incorporating innovative 
'collective action clauses' (CACs), in exchange for the U.S. Treasury embracing the contractual approach to reforms (Taylor, 2007: 111-32). The transaction was successful because investors did not demand a premium for the contractual innovation, and ever since then, most sovereign bond issues under U.S. law have incorporated the said clauses at no obvious additional cost (Bradley et al., 2010: 297, 320).

The impetus to continue to reform the rules and practices of international finance subsided for about a decade, until the Greek financial crisis erupted in 2010-12 and led to a massive official rescue underwritten by the European Union (EU) and the IMF - only to result in a record-breaking default more than twice the size of Argentina's a decade earlier. But it was not until long-simmering litigation against Argentina began to yield victories for holdout creditors in 2012-14 that the G-20 countries mobilized to introduce a further contractual reform.

The crisis in Greece engendered regrets in official and academic circles because the passage of time revealed that IMF and EU emergency lending had been utilized in part to finance the exit of private creditors in the two years ahead of the restructuring of government debt in March 2012 (IMF, 2014: 12). Moreover, while the eventual restructuring of obligations in the hands of local and foreign private investors achieved a very high creditor participation rate of 97 percent, despite being pre-emptive and involving massive debt forgiveness, the IMF and mostly European policymakers and academics bemoaned the fact that it was not 100 percent comprehensive. The leakage of 3 percent was accounted by the fact that the owners of 19 of the 36 Greek government bonds subject to English law had not participated in the debt relief operation, because blocking majorities of holdout creditors had exercised their rights under those bonds' CACs to prevent any changes to their payment terms (IMF, 2013: 28).

The saga of litigation against Argentina on the part of holdout creditors who refused to exchange their original bonds for new ones worth a fraction - bondholders who accounted for 7 percent of the government's bonded debt in default as of 2002 - became a source of concern to the IMF and a variety of governments and academics once the holdouts finally scored important judicial victories. These included a June 2014 U.S. Supreme Court decision not to hear Argentina's appeal of lower federal court rulings which (a) had found Argentina in breach of a clause in its defaulted bonds - the so-called pari passu clause - pledging to treat all bondholders equally, and (b) had prohibited Argentina from making payments to creditors who had accepted new bonds unless it paid also holdout creditors what they were owed. The governments of Brazil, France, Mexico and the United States filed legal briefs before the U.S. Supreme Court, stating that these rulings would have a negative impact on the orderly and timely conduct of sovereign debt restructurings by encouraging more bondholders to resist going along with future sovereign debt restructuring. Several law firms, academics, policy groups, and international bodies likewise expressed their opposition to the verdicts (IMF, 2014: 7-13). 


\section{THE CASE FOR STATUTORY AND CONTRACTUAL REFORMS}

The most outspoken critic of the existing international financial architecture has been Joseph Stiglitz, the heterodox economist who in numerous books, articles, opinion pieces and speeches has called for a comprehensive international bankruptcy procedure to ensure the proper resolution of sovereign debt crises (Guzman and Stiglitz, 2016a).(1) Stiglitz has gone beyond the confines of academia to flog his ideas, serving as an advisor to, and public advocate and expert witness for, Presidents Néstor and Cristina Kirchner of Argentina in their quest to impose the punishing 2005 debt restructuring on holdouts who had court-validated rights to refuse any such cramdown (Johnson 2014). However, Stiglitz has been surprisingly short on concrete reform proposals, putting forth that "there should be a global agreement that no country can surrender its sovereign immunity (even voluntarily)" to creditors, combined with the establishment of "an oversight commission [made up of government representatives] with the mission of mediating and supervising the [debt] restructuring process" of sovereigns (Guzman and Stiglitz, 2016a: 22).(2)

José Ocampo, Stiglitz's colleague at Columbia University, has been inspired by the disputesettlement process at the World Trade Organization (WTO), which follows three consecutive stages with clear deadlines: one of voluntary negotiations, a second of mediation, and a final of arbitration, if the former two fail. He has been advocating for a similar mechanism to be established for sovereign debt restructurings, possibly to be hosted by the IMF but independent of it, to ensure a process that would be efficient, impartial and speedy with a result that is binding on all parties involved (Ocampo, 2016).

Jürgen Kaiser, of Jubilee Germany, has been advocating for a state insolvency process through international arbitration, an updated version of proposals which first circulated in the 1990s, because in his view both the sovereign debtor as well as good-faith creditors have the most to win through an impartially facilitated compromise.(3) He does not call for a new international organization, nor a costly bureaucracy, but rather for a liaison office to arrange for ad hoc mediation, conciliation and arbitration services, with panels nominated freely by the parties based on a mutual agreement, whenever sovereigns are looking for a comprehensive solution to their looming or acute sovereign debt problems (Kaiser, 2016).

As of mid-2016, none of these statutory reforms or any others had gained traction, whereas certain draft contractual reforms had earned strong support in G-20 official circles, were adopted by law in Europe, and have been incorporated by a number of sovereign debtors and accepted by bondholders elsewhere. The first reform involves the introduction of so-called 'super-CACs' containing aggregation provisions. Their purpose is to limit the ability of holdout creditors to impede restructurings acceptable to a supermajority of creditors, because whereas voting under 
existing CACs is to be carried out by holders of one bond series at a time, the new clauses contemplate aggregated, simultaneous voting across all debt instruments subject to a restructuring with binding effect on all bond series.

In the wake of growing concern that the Greek restructuring of March 2012 would encourage more holdouts in the future, the European Council decided, and the treaty establishing the European Stability Mechanism enshrined, that as of the start of 2013 a new aggregation clause would be mandatorily included in all new euro-area government securities with a maturity greater than one year.(4) In August 2014, following an extensive consultative process with financial intermediaries, the International Capital Market Association (ICMA) published suggested wording for aggregation CACs to be utilized by sovereign issuers around the world, and these clauses have since come into use with Mexico once again taking the lead (Makoff and Kahn, 2015; Gelpern et al., 2016).(5) During the period from 1 October 2014 to 31 July 2015, there were 73 international sovereign bond placements, by 37 different sovereign issuers, for a total nominal principal amount of approximately US\$ 86 billion. And, out of these, 42 bonds, representing about 60 percent of the nominal principal amount of total issuance, included the super-CACs (IMF, 2015: 4).

The second reform involved the introduction of a model pari passu clause, responding to concerns about the implications of the Argentina litigation for future bonds, as voiced by the IMF and G-20 governments (IMF, 2015: 2-3). The proposed language was likewise first published by ICMA in August 2014, intending to mitigate the risk that other courts would read into the clause the interpretation given by the U.S. courts in the case of Argentina's clause. It explicitly states that while a debt will rank pari passu with all other unsecured debt of the issuer, there is no implied requirement that the issuer must pay its debts at the same time (technically, on an equal or ratable basis).(6) The model pari passu clause has been adopted in tandem with the super-CACs by most sovereigns issuing new debt between 1 October 2014 and 31 July 2015 (IMF, 2015: 8).

\section{THE CASE AGAINST STATUTORY REFORMS}

It would appear that those who have been advocating for statutory reforms of the international financial architecture are not persuaded that the latest round of contractual reforms is sufficient to remedy whatever deficiencies they perceive. Joseph Stiglitz, for instance, recently wrote about Argentina's settlement with its holdout creditors:

'This resolution will carry a high price for the international financial system, encouraging other funds to hold out and making debt restructuring virtually impossible' (Guzman and Stiglitz, 2016b)

His colleague José Ocampo, for his part, had previously written: 
'The most important effect of the U.S. rulings, however, is that they discourage any future voluntary debt renegotiation, for obvious reasons: if investors know they have a chance to claim full payment through the courts, why would they take part in any restructuring?' (Ocampo, 2014)

It is not hard to disagree with these pessimistic assessments for several reasons. First, the record shows that most sovereign debt restructurings have been handled expeditiously despite the absence of a world sovereign bankruptcy regime. Neither the threat nor the act of litigation, nor isolated instances of 'rogue creditor' behavior, have thwarted the debt restructurings that have needed to be accomplished.

According to a Moody's analysis of 34 sovereign bond restructurings from 2008 through early 2013, the evidence shows that negotiations between sovereigns and their private creditors have proceeded fairly quickly, such that on average debt restructurings were completed within seven months after the start of negotiations.(7) In only two cases have holdout creditors represented more than ten per cent of the value of outstanding bonds, and in just one of those instances - that of Argentina - did the holdouts engage in persistent litigation (Duggar, 2013). This is the case because most sovereigns have made reasonable debt relief demands from their creditors and have pursued good-faith negotiations - whereas Argentina did neither. In fact, the unilateral, coercive and aggressive mode with which the authorities in that country went about managing, defaulting and restructuring their debt obligations stands out in a comprehensive academic study of the nature of past sovereign debt disputes:

'The well-known case of Argentina from 2001 to 2005 displays an exceptional degree of coerciveness, as the government officially declares a default, sticks to the proclaimed moratorium by stopping all payments to its bondholders for four years, freezes foreign assets, and rejects any meaningful negotiations' (Enderlein et al., 2012: 261).

Second, by now most international sovereign bonds include the first-generation CACs binding investors in any one debt instrument to the decisions of a supermajority, and as mentioned above, the bulk of new bonds issued since late 2014 include the super-CACs. Indeed, whereas at the end of 2002 a mere one-third of international sovereign bonds featured CACs, by mid-2014 that proportion had risen to about 80 percent (IMF, 2014: 17). While the first-generation CACs do not eliminate the holdout problem witnessed during the Greek debt restructuring of 2012, which was a minor one involving creditors obtaining blocking position in particular bond series, they would have minimized Argentina's significant holdout problem if they had figured in that country's obligations. However, because Argentina's default in late 2001 involved mostly bonds issued during the 1990s, very few of them included CACs and the bulk required the unanimous consent of their owners for any 
amendments to their payment terms - the feature which attracted, and then empowered, holdouts (Duggar, 2014).

Third, sovereigns are free to repurchase whichever bonds they regard as potentially problematic - for instance because they do not feature first- or second-generation CACs - while issuing new ones with whatever promissory language they are prepared to honor. The fact that no sovereign issuer is known to have engaged in such a liability-management operation to accelerate the incorporation of the enhanced contractual provisions (IMF, 2015: 10) suggests that most sovereigns do not contemplate ever managing, defaulting on, and restructuring their debt obligations in the same unilateral, coercive, aggressive and ultimately self-defeating manner as Argentina did.

Fourth, pari passu language is usually not as holdout-friendly as was the one in Argentina's indentures from the 1990s at the heart of the country's default. Pari passu clauses are a standard feature of sovereign bond contracts, but there are three major formulations, the most common of which appears in the majority of sovereign bonds issued over the past two decades, and in almost all bonds issued earlier - and it is not suitable for Argentina-style litigation (Duggar, 2014: 2).(8) Moreover, there already is one case where a holdout creditor tried but failed to use the ruling in the Argentina case as a suitable precedent. The Export-Import Bank of the Republic of China (Taiwan) chose not to participate in the restructuring of Grenada's debt in 2005, and in March 2013 the bank filed a lawsuit against Grenada based on the pari passu violation argument used against Argentina. However, in August 2013, the federal district court in New York ruled that the Argentina decision was limited to Argentina's unique set of circumstances and did not apply to Grenada's (Alfaro, 2015: 70-71).

Fifth, the threat of holdout creditors actually has been a force mainly for good in the international financial landscape. Sovereign distressed-debt investors have been characterized as disruptive to the restructuring process and unfair to the creditors that participate in restructurings. However, just like distressed-debt investors can expedite business reorganizations and protect goingconcern enterprise values in the private sector (Goldschmid, 2005), 'vulture investors' can and often do play a salutary role in the sovereign debt context by advancing creditor rights (Fisch and Gentile, 2004: 1097-1101).

Unlike many risk- and confrontation-averse institutional and retail investors, opportunistic investors are more likely to challenge aggressive sovereigns and motivate them to make a better offer than they would otherwise make to the meeker creditors. In the case of Argentina, tens of thousands of elderly retail investors benefited from the litigation spearheaded by the distressed-debt investors (Mander, 2016) - and hundreds of thousands more would have benefited if the wheels of justice had only turned faster. Holdout litigation can also serve as a potential check on opportunistic defaults by sovereign debtors, and it was sorely missing in the blatant case of Ecuador in 2008-09 (Porzecanski, 2010). It boggles the mind that so much of the academic and policymaking literature has ignored the 
realistic possibility that rogue sovereign debtors like Argentina, rather than holdout private creditors, are the ones that pose the greater threat to the integrity and efficiency of the international financial architecture (Porzecanski, 2005: 331).

Sixth, Argentina's behavior during 2002-2015 demonstrates why none of the proposed statutory reforms would work in the case of a similarly recalcitrant, dishonorable sovereign debtor. If governments around the globe were to agree not to surrender their sovereign immunity voluntarily when accessing the leading financial markets, as Stiglitz has proposed, then uncreditworthy sovereigns like Argentina would never be able to raise funding outside their own borders. Argentina recently sold the largest-ever amount of bonds placed abroad by any emergingmarket economy after making up with its creditors (Platt and Moore, 2016) - but only after surrendering its sovereign immunity irrevocably, as it had always done prior to the 2001 default.

And if there were to be an oversight commission made up of government representatives with the mission of mediating and supervising the debt restructuring process of sovereigns, then Argentina would not have accomplished a restructuring when it wanted it, because in 2002 the country was barely on speaking terms with the official international community. In fact, Argentina at the time also defaulted to its official bilateral creditors (namely, the world's export-credit and foreign-aid agencies) - and it remained in default to them for over a dozen years (Mander, 2014). It is hard to conceive that the country would have turned to a group of foreign government officials for mediation and supervision in the early 2000s, when it was in such a confrontational mood.

In terms of a dispute-settlement process for sovereign debtors akin to that for trade disputes at the WTO, that would not have worked well, either. During the past two decades, Argentina has been the target of more trade complaints triggering dispute-settlement procedures than any country in Latin America - more than any other developing country except for China and India, in fact (WTO, 2015). In recent years, Argentina went through a heated WTO dispute-settlement process because of the stringent import restrictions that it imposed after 2010. The country was found guilty of breaking the WTO rules in 2014 and again (after an appeal) in 2015. It subsequently pledged to remove the restrictions by end-2015, but as of mid-2016, even the new government in Buenos Aires had yet to abolish all the import controls that it was supposed to remove (Baker \& McKenzie 2015; WTO 2016). This track record does not inspire confidence that any WTO-like, debt-resolution mechanism would have met Argentina's approval in the early 2000s unless it had validated the country's aggressive debt-relief objectives.

As concerns the applicability of a state insolvency process through international arbitration, the fact is that since 2001 Argentina has likewise been the target of numerous claims filed with tribunals under the International Centre for Settlement of Investment Disputes (ICSID), the United Nations Commission on International Trade Law (UNCITRAL), and the International Chamber of Commerce (ICC) - the most ever against a country party to those conventions. Argentina dragged 
all the cases out for as many years as possible through endless challenges and appeals, and whenever it lost arbitrations definitively, it either did not pay the resulting awards or it paid them in part after long delays (Cancel 2013, Porzecanski, 2015). In this regard, Argentina's rogue behavior in connection with arbitration proceedings was consistent with its refusal to obey and pay foreign court judgments, and it is highly suggestive of the lack of efficacy that an arbitral vehicle for state insolvency matters would have had in Argentina's case.

Finally, advocacy for statutory reforms is pointless because there has not been a willingness on the part of most governments and most private creditors to depart from the current financial architecture. Governments are evidently unwilling to cede their sovereignty when it comes to such important matters as their creditworthiness and capacity to respond quickly to any economic or financial emergency they may confront. And bond investors and commercial lenders are likewise unwilling to cede their creditor rights to a mediation, conciliation, or arbitration process without the inclination and enforcement powers to confront wayward governments - especially now that the U.S. judiciary proved able to checkmate an insubordinate sovereign such as Argentina.

In sum, sovereign debt restructurings may experience marginal changes as a result of recent modifications in contractual terms being incorporated into new bond issues, but for the most part they will likely resemble what has generally worked so well in recent decades to the satisfaction of most governments and most private creditors. The statutory reforms that have been proposed to date are highly unlikely to gain traction for a variety of reasons, including the prospect that they would have been stymied if they had been in place and were confronted with a rogue sovereign debtor such as Argentina.

\section{NOTES}

1 'The current non-system does not achieve the described objectives of restructuring. Instead, it creates a host of inequities as well as inefficiencies. It overpenalizes debtors in distress, causing delays in the recognition of the problems. It leads to the 'too little, too late' syndrome. In some cases, there is too much lending - and too much suffering later on; in other cases, there may be too little lending. Moreover, the legal frameworks permit a situation in which a few specialized agents (the vulture funds) can block the finalization of a restructuring, imposing large costs on the debtor and on other creditors' (Guzman and Stiglitz, 2016a: 10).

2 'The commission would not rule over different alternatives. Instead, the sovereign would finalize the process with a final proposal and the commission would produce statements about the reasonability of the process and the final proposal. This approach would serve to legitimate the restructuring or, alternatively, to legitimate positions that speak of illegitimate restructurings.' (Guzman and Stiglitz, 2016a: 22). 
3 In the mid-1990s Barry Eichengreen and Richard Portes had called for the establishment of an independent agency that 'could provide mediation and conciliation services in negotiations between the debtor and creditors and, if desired by the parties themselves, binding arbitration' (Eichengreen and Portes, 1995: 43), but the earliest proposal for an ad-hoc debt arbitration process was put forth by the Austrian economist Kunibert Raffer in the late 1980s (Raffer, 1990). With some of its features further developed, this concept was later on adopted by NGOs campaigning for debt relief as part of the Jubilee 2000 Campaign, and is nowadays referred to as the Fair and Transparent Arbitration Process (Fritz and Hersel, 2002).

4 Bonds issued by euro-area sovereigns are required to include a CAC that allows for either a seriesby-series or a two-limb aggregated voting procedure. The latter enables differential treatment among creditors. For additional background and details, see Hofmann, 2014.

5 In order to accommodate stylistic differences between legal markets, ICMA published in May 2015 two different versions of the model clauses, one for English-law bonds and another for New Yorklaw bonds, see www.icmagroup.org/assets/documents/Resources/ICMA-Standard-CACs-PariPassu-and-Creditor-Engagement-Provisions---May-2015.pdf, accessed 23 August 2016.

6 ICMA (2014); see also the prior note and citation for the May 2015 version of the provision as tailored for sovereign bonds governed by New York law.

7 This average would be considerably shorter if the sample were to exclude the longest delays, which had to do with unique restructuring strategies and the parallel restructuring of official sector and commercial loan debt simultaneously with the restructuring of the bond instruments (Duggar, 2013).

8 The pari passu clause in the old Argentine bonds reads as follows: ' $\mathrm{t}$ ] he Securities will constitute ... direct, unconditional, unsecured and unsubordinated obligations of the Republic and shall at all times rank pari passu without any preference among themselves. The payment obligations of the Republic under the Securities shall at all times rank at least equally with all its other present and future unsecured and unsubordinated External Indebtedness ...' (Moody's, 2014: 2). The U.S. federal courts interpreted it as requiring equal ranking of payment obligations under the relevant debts, and they prevented Argentina from making payments to the restructured bondholders without first making a 'ratable payment' to the holdout creditors (IMF, 2014: 37-44).

\section{REFERENCES}

Alfaro, Laura (2015) 'Sovereign Debt Restructuring: Evaluating the Impact of the Argentina Ruling', Harvard Business Law Review 5(1): 47-71. 
Baker \& McKenzie (2015), 'Argentina Replaces DJAIs with Import Monitoring System', Available at http:/ /www.internationaltradecomplianceupdate.com/2015/12/22/argentina-replaces-djais-withimport-monitoring-system/ [accessed 23 August 2016].

Bradley, Michael, James D. Cox and Mitu Gulati (2010) 'The Market Reaction to Legal Shocks and Their Antidotes: Lessons from the Sovereign Debt Market', Journal of Legal Studies, 39(1): 289-324. Cancel, Daniel (2013) 'Argentina Settles \$677 Million Arbitration Cases with Bonds’, Bloomberg News, 18 October.

Duggar, Elena (2013) 'The Role of Holdout Creditors and CACs in Sovereign Debt Restructurings', New York: Moody's Investors Service, 10 April.

Duggar, Elena (2014) 'Impact of Court Ruling on Argentina's Debt on Future Sovereign Debt Restructurings Is Likely Limited', New York: Moody's Investors Service, 3 March.

Eichengreen, Barry and Richard Portes (eds.) (1995) Crisis? What Crisis? Orderly Workouts for Sovereign Debtors, London: Centre for Economic Policy Research.

Enderlein, Henrik, Christoph Trebesch and Laura von Daniels (2012) 'Sovereign Debt Disputes: A

Database on Government Coerciveness during Debt Crises', Journal of International Money and Finance 31(2): 250-266.

Fisch, Jill E. and Caroline M. Gentile (2004) 'Vultures or Vanguards: The Role of Litigation in Sovereign Debt Restructuring', Emory Law Journal 53(Special Ed.): 1043-1113.

Fritz, Thomas and Philipp Hersel (2002) Fair and Transparent Arbitration Process: A New Road to Resolve Debt Crises, Berlin: Discussion Paper FDCL-Verlag, August.

Gelpern, Anna, Ben Heller and Brad Setser (2016) 'Count the Limbs: Designing Robust Aggregation Clauses in Sovereign Bonds', in Martin Guzman, José A. Ocampo, and Joseph E. Stiglitz (eds.), Too Little, Too Late: The Quest to Resolve Sovereign Debt Crises, New York: Columbia. Goldschmid, Paul M. (2005) 'More Phoenix than Vulture: The Case for Distressed Investor Presence in the Bankruptcy Reorganization Process', Columbia Business Law Review 2005(1): 191 274.

Guzman, Martin and Joseph E. Stiglitz (2016a) 'Creating a Framework for Sovereign Debt Restructuring that Works', in Martin Guzman, José A. Ocampo, and Joseph E. Stiglitz (eds.), Too Little, Too Late: The Quest to Resolve Sovereign Debt Crises, New York: Columbia.

Guzman, Martin and Joseph E. Stiglitz (2016b) 'How Hedge Funds Held Argentina for Ransom', New York Times, 1 April.

Hofmann, Christian (2014) 'Sovereign-Debt Restructuring in Europe Under the New Model Collective Action Clauses', Texas International Law Journal 49(2): 383-441.

International Capital Market Association (2014), 'Standard Pari Passu Provision for the Terms and Conditions of Sovereign Notes', Available at www.icmagroup.org/assets/documents/Resources/ICMA-Standard-Pari-Passu-Provision-August2014.pdf, accessed 23 August 2016.

IMF (2013) 'Sovereign Debt Restructuring: Recent Developments and Implications for the Fund's Legal and Policy Framework', 26 April, International Monetary Fund. 
IMF (2014) 'Strengthening the Contractual Framework to Address Collective Action Problems in Sovereign Debt Restructuring', 2 September, International Monetary Fund.

IMF (2015) Progress Report on Inclusion of Enhanced Contractual Provisions in International Sovereign Bond Contracts, 17 September, International Monetary Fund.

Kaiser, Jürgen (2016) 'Making a Legal Framework for Sovereign Debt Restructuring Operational', in Martin Guzman, José A. Ocampo, and Joseph E. Stiglitz (eds.), Too Little, Too Late: The Quest to Resolve Sovereign Debt Crises, New York: Columbia.

Mander, Benedict (2014) 'Argentina Reaches Landmark Deal with Paris Club Creditors', Financial Times, 29 May.

Mander, Benedict (2016) 'Argentina to Pay Italian 'Holdout' Creditors', Financial Times, 2 February. Makoff, Gregory and Robert Kahn (2015) Sovereign Bond Contract Reform: Implementing the New ICMA Pari Passu and Collective Action Clauses, Waterloo: CIGI Paper No. 56, February. Ocampo, José A. (2014) 'Implications of the U.S. Supreme Court Ruling on Argentina,' Financial Times, 23 June.

Ocampo, José A. (2016) 'A Brief History of Sovereign Debt Resolution and a Proposal for a Multilateral Instrument', in Martin Guzman, José A. Ocampo, and Joseph E. Stiglitz (eds.), Too Little, Too Late: The Quest to Resolve Sovereign Debt Crises, New York: Columbia.

Platt, Eric and Elaine Moore (2016) ‘How Did Argentina Pull Off a \$16.5bn Bond Sale?’ Financial Times, 20 April.

Porzecanski, Arturo C. (2005) 'From Rogue Creditors to Rogue Debtors: Implications of Argentina's Default', Chicago Journal of International Law 6(1): 311-332.

Porzecanski, Arturo C. (2010) 'When Bad Things Happen to Good Sovereign Debt Contracts: The Case of Ecuador', Law \& Contemporary Problems 73(4): 251-271.

Porzecanski, Arturo C. (2015) The Origins of Argentina's Litigation and Arbitration Saga, 2002-

2014, Washington, DC: American University School of International Service Research Paper No. 2015-6.

Raffer, Kunibert (1990) 'Applying Chapter 9 Insolvency to International Debts: An Economically Efficient Solution with a Human Face', World Development 18(2): 301-313.

Taylor, John B. (2007) Global Financial Warriors: The Untold Story of International Finance in the Post-9/11 World, New York: W.W. Norton.

WTO (2015), 'Dispute Settlement: W'TO Disputes Reach 500 Mark', 10 November, Available at https://www.wto.org/english/news_e/news15_e/ds500rfc_10nov15_e.htm, [accessed 23 August 2016].

WTO (2016), 'Dispute DS444: Argentina: Measures Affecting the Importation of Goods', Available at https://www.wto.org/english/tratop_e/dispu_e/cases_e/ds444_e.htm, [accessed 23 August 20 